\title{
THE TRANSMISSION AND BIBLIOGRAPHIC STUdY OF THE PIGAFETTA ACCOUNT: SYNTHESIS AND UPDATE
}

\author{
Clayton McCarl \\ University of North Florida
}

\begin{abstract}
AвsTRACt: For its value as a historical source and as a singular piece of writing, Antonio Pigafetta's account of the Magellan-Elcano expedition has appeared in diverse places, and over the centuries. Numerous scholars have worked to establish the history and nature of those editions and translations. This study pursues three objectives related to Pigafetta's account: to articulate a synthesis of the publication history; to summarize the development of research on that transmission; and to identify trends, controversies and possible gaps in that scholarship.
\end{abstract}

KeYwORDS: Antonio Pigafetta; Magellan; book history; bibliography.

A tRANSMisSÃo E O ESTUdo BibliográFico do relato de Pigafetta: síntese e atualização

Resumo: Por seu valor como fonte histórica e como peça singular de escrita, o relato de Antonio Pigafetta sobre a expedição Magalhães-Elcano apareceu em diversos lugares, e ao longo dos séculos, Numerosos estudiosos trabalharam para estabelecer a história e a natureza dessas edições e traduções. Este estudo persegue três objetivos relacionados com o relato de Pigafetta: articular uma síntese da história da publicação; resumir o desenvolvimento da pesquisa sobre essa transmissão; e identificar tendências, controvérsias e possíveis lacunas nessa erudição.

Palavras-chave: Antonio Pigafetta; Magalhães; livro de história; bibliografía.

The history of European maritime expansion in the Early Modern period is a story of ships crossing seas, but also of books moving across linguistic, cultural and geographical boundaries. For its value as a historical source and as a singular piece of writing, Antonio Pigafetta's account of the Magellan-Elcano expedition has appeared in diverse places, and, over the centuries, numerous scholars have worked to establish the history and nature of those editions and translations. As we observe the five-hundredth anniversary of the journey, this study seeks to pursue three objectives related to Pigafetta's account: to articulate a synthesis of the publication history; to summarize the development of 
research on that transmission; and to identify trends, controversies and possible gaps in that scholarship. ${ }^{1}$

\section{TRANSMISSION}

After returning to Spain in I522, Pigafetta composed an account that is understood to have existed first as a summary or summaries — unknown today and later as a fuller version he sought to publish in 1524, apparently without doing so. Four known manuscripts document the latter, or some version of it. One is in Italian at the Ambrosiana Library, Milan, and three others in French are located at other repositories.

The first printed version, Le voyage et nauigation, appeared in Paris around 1525. That French text then informed all other editions through the end of the eighteenth century. It was translated to Italian with abridgement, and printed in the volume Il Viaggio fatto dagli Spagnivoli (1536, probably Venice). Giovanni Battista Ramusio included that translation in the first volume of Navigationi et Viaggi (Venice, 1550), and it figured as well as in later editions of that collection (1554, 1563, 1588, I606, I613). Richard Eden printed a translation, based on the version in Ramusio, first in his edition of the Decades of Peter Martyr (London, 1555), and later in History of Trauayle (London, I577). Eden's version was likely the source for the version in Purchas His Pilgrimes (London, I625-

' Due to space considerations, this study is bound by limitations in scope and in the construction of the bibliography. Pigafetta's treatise on navigation has often appeared with his account of the expedition, but is not considered here, nor is the letter by Maximilian of Transylvania. With limited exceptions deemed to be significant, this essay excludes consideration of extracts, adaptations and narrative accounts based on Pigafetta's text, and versions in languages other than English, French, German, Italian, Portuguese and Spanish. To conserve space and reduce redundancy in the bibliography, I employ the following conventions: I list under Pigafetta full details for all versions that can be reasonably understood as editions and translations, and cross-reference those in an abbreviated fashion in the corresponding entries for editors' introductions. When versions of Pigafetta's text are included in volumes that also present other texts (as in the I874 Hakluyt edition), however, I have included full information in both the entry under Pigafetta and in the entry for the respective introduction, as in such cases the introduction is to the entire volume, not just to the Pigafetta text. I mention reprints only in the body itself (employing the abbreviation rpt.), and only by year. I have shortened titles and other information wherever possible. 
I626, rpt. 1905-1907, 1965). M.C. Sprengel published a translation to German (Leipzig, I784), derived, according to Leoncio Cabrero (1985: 36), from the version in Ramusio.

In 1800 , Carlo Amoretti published in Milan a new version based on the Ambrosiana manuscript, to that time unknown. The following year, Amoretti's own translation to French was printed in Paris ${ }^{2}$ and a German translation from that French appeared in Gotha. Both included Amoretti's introduction, as did the English translation of the 1800 edition that John Pinkerton included in A General Collection (London, I8ı2, rpt. I8ı9).

Numerous editions in various languages appeared in the second half of the nineteenth century. Edouard Charton published a French version in the collection Voyageurs anciens et modernes (Paris, 1855). The Hakluyt Society published an English translation and edition, based on Amoretti, by Lord Stanley of Alderley in The First Voyage round the World (London, i874; rpt. c. 1963, 20 Io twice, 2016). The Bibliothèque Nationale de France registers a French version printed in Limoges, apparently in I884 (rpt. possibly 2008). Edward Arber's The First Three English Books on America (Birmingham, 1885), contains a reprinting of the pre-1800 version in Eden (I577) (Robertson I906b, 290-292). In 1888, a reedition of Amoretti's i80 i translation was published in Paris, and that same year, José Toribio Medina printed in Santiago, Chile, what appears to be both the first Spanish translation and the first version made in the Americas. In I894, Andre da Mosto published in Rome a new edition of the Ambrosiana manuscript, and in I899, Manuel Walls y Merino published another Spanish translation in Madrid, based on the r800 edition (rpt. 200 I).

At the beginning of the twentieth century, James Alexander Robertson published a new English translation from the Ambrosian manuscript (Cleveland, 1906). In 1922, Federico Ruiz Morcuende printed in Madrid a new translation into Spanish of Amoretti's i80 I French text (rpt. 1927, 1934, 1941, 1943, 1946, 1954, 1963). In 1923, Jean Denucé published in Paris an edition of one the French manuscripts, with variants from the other three manuscripts, and Camilo Manfroni published in Milan an edition in Italian in 1928. A translation to Portuguese — perhaps the first - appeared in 1938 in Lisbon.

The second half of the twentieth century also saw numerous new editions. In 1956 Léonce Peillard published in Paris a modernized French version based

2 The text itself bears the date «l'an IX» (revolutionary calendar), corresponding to I800. 
on the same manuscript edited by Denucé (rpt. 1964, I970, 1984, I991, I999 twice, 2005). In 1957, a translation to Spanish by an F. Ros was published in Madrid. Charles Nowell included Robertson's 1906 translation in a collection published in 1962 in Evanston, Illinois, and George Sanderlin published a somewhat abridged edition in English in New York in I964, based on the same translation. A Portuguese translation was printed in 1966, and an English version was published in Manila in I969, based on Robertson (1906). That same year, Paula Spurlin Paige printed in New Jersey a facsimile edition and translation into English of a copy of the c. 1525 French version, and R. A. Skelton printed in Connecticut a translation to English from one of the French manuscripts (rpt. 1994, 1996, 2016). In 1970, Armando Braun Menéndez published in Buenos Aires a new edition of Medina's Spanish translation (rpt. 1997). Leoncio Cabrero printed in Madrid a Spanish edition based on the 1957 F. Ros translation in 1985 (rpt. 1988, 2002), and translations to Portuguese appeared in 1986 in Brazil and Portugal (the latter rpt. 1990). In 1987, Mariarosa Masoero published in Rovereto, Italy, a new edition based on the Ambrosiana manuscript, as did both Luigi Giovannini in Milan and Michele Amendolea in Rome in I989. Mario Pozzi published an abbreviated Italian version based on the Ambrosiana manuscript in Milan in I99I, and in 1994 another edition and facsimile of that manuscript. In 1995, T. J. Cachey published in New York a translation to English from the 1987 Masoero edition (rpt. 2007). In 1998, Diego Bigongiari published a Spanish edition in Buenos Aires, as did Ana García Herráz and Mario Pozzi in Valencia. That same year, a translation to Portuguese was printed in Mem Martins. In I999, the following were published: a new Spanish translation by Isabel de Riquer in Barcelona, and a new Italian edition by Andrea Canova in Padua.

In the first two decades of the twenty-first century, several editions have appeared. In 2004, Martín Casariego published in Madrid a new edition in Spanish and in 2007, Xavier de Castro published a version in Paris in a collection in French, reprinted in 20I0. A new German edition was published in 2013 (rpt. 2017).

\section{THE BIBLIOGRAPHICAL SCHOLARSHIP}

Antonio de León Pinelo's i629 Epitome appears to be the first bibliographical work to register Pigafetta's account, mentioning (perhaps speculatively) a manuscript, the c. I525 French text, and the version in Ramusio (88). In the follow- 
ing century, Andrés González de Barcia reproduced that entry, with some modification, in his expanded edition of the Epitome (I737-I738: vol. II, col. 665). At the end of that century, Nicolás Antonio (I788: vol. II, 376) registers the c. I525 French edition in his Bibliotheca Hispana Nova.

In the first half of the nineteenth century, Amoretti discussed the history of the publication of the text in his introduction to his edition (I800: XXXIV-XLIII, XLIX-LII). Antonio de Alcedo (I964-65 [I807]: vol. II, I57) copies with slight changes part of the entry in León Pinelo (I629, 88), William Marsden (ı827, 95) registers Amoretti's I 800 Italian edition and I 80 I French translation, and Henri Ternaux-Compans registers the i80 I French text (I83I: ${ }^{\circ}$ I54) and the c. 1525 French edition and Eden's 1555 collection (1837: n ${ }^{\circ}$ I, 70). John Thomas Payne and Henry Foss register the c. I525 French and 1536 Italian versions, as well as Amoretti's i800 edition (I842: vol. II, 548-549).

The second half of the nineteenth century saw even greater attention paid to the Pigafetta account. A brief bibliographic study follows the French version in Voyageurs anciens et modernes (1854-1857: vol. III, 354), and Charton includes a longer bibliography at the end of his i855 edition (353-356). Jean George Théodore Graesse registers the c. I525 French and I800 Italian editions (I859-69: vol. v, 289), as does Jacques-Charles Brunet (I999 [I862]: vol. IV, 650-65I). Henry Harisse provides a narrative account of Pigafetta's writing of his text, the circumstances leading up to the publication of the c. 1525 French version, the publication of the text translated back into Italian the next decade, and Amoretti's preparation of the I800 Italian edition (I866: 229, 247-25I). Joseph Sabin registers the c. I525 French version, Amoretti's I800 Italian edition, the 180 I French and German translations, and the I874 Hakluyt volume (I96I-I962 [I868-?]: no 62803-62807). In his introduction (I874: L-LVI), Lord Stanley discusses the manuscripts and the early editions, and John Russell Bartlett provides a detailed description of the C. I525 French version (I875 [I865]: 9092). Charles Alfred Leclerc registers Amoretti's i 800 Italian and I80 I French editions (I867: $n^{0}$ II70-II7I; I878: $n^{0} 448-449,2439-2440$ ). Justin Winsor considers the manuscripts and the c. 1525, I536 and I800 editions (1886: 613-615). Da Mosto touches on related matters in the introduction to his edition (I894: 9-II). In 1897, Medina discussed (vol. I, 8-12) the c. I525 French version, as well as Amoretti's 1800 and I80I versions, and he reprinted that same discussion the following year (1958-1962 [I898-1907]: vol. I, 97-10I).

In the first half of the twentieth century, Robertson discussed briefly matters related to transmission in the preface to his edition (I906a), and provided 
the most extensive discussion to date of the manuscripts and printed editions in the appendix (1906b). Antonio Palau y Dulcet registered in Manual del librero hispano-americano the c. I525, I536, and I80o editions, as well as numerous of the subsequent versions in various languages (1948-1980: $\mathrm{n}^{0}$ 225739-225755). In the second half of the twentieth century, Charles E. Nowell discussed the I906 version (1962: 4), Léonce Peillard considered the four manuscripts in the preface to his 1956 edition (48-57), and Howard H. Peckam (I969: XII-XV) and R. A. Skelton (1969: 8-9, I3-18) examined the transmission of the Pigafetta story more extensively. Cabrero (1985: 34-39) reviewed the historical sources and provided a listing of editions, as did Mario Pozzi, more briefly in I991 (518-20). In 1994, Pozzi considered the writing of the account and the manuscripts and editions (20-30). In the introduction to his edition (I995: XLI-LVII), Theodore J. Cachey discussed the circumstances around the c. 1525 edition, as well as the manuscripts.

\section{TRENDS, CONTROVERSIES AND GAPS}

As this review of the bibliographical scholarship makes clear, most sources provide fragmentary versions. The c. 1525 and 1800 editions comprise the center of gravity of this body of studies, a logical circumstance since both are in a sense first editions, each the starting point for a separate textual tradition. Different sources, however, include different combinations of other editions and translations, and until Robertson (1906b), no study stands out as exhaustive. In many ways Robertson's work has not been superseded, but necessarily misses over a hundred years of more recent textual history. Skelton (1969) and Cachey (1995) are the other two major studies in the twentieth century, but neither was designed to be comprehensive, and, given the quantity of editions published since 1995, also cannot tell the entire story.

One of the most obvious deficiencies in the current scholarship is the lack of attention to nearly all the versions in Spanish and Portuguese. Robertson (1906b) misses the Spanish translation by Medina, as do Skelton (1969) and Cachey (1995), omitting mention as well of all the subsequent Spanish versions published in the twentieth century. None of the Portuguese texts appear to be contemplated in the bibliographic scholarship. Beyond the matter of the exclusion of these editions, some larger questions present themselves. Why was no version of the Pigafetta story produced in Spanish until the Medina 
translation, nearly four centuries after the c. 1525 edition? Why, subsequently, were so many editions, translations and reprints produced in Spanish since that time - more, it seems, than in any other language? Why do we find no version in Portuguese until I938?

Another, perhaps lesser, question surrounds the 1784 German version, which appears to have been the first version in any language since 1626. Why were no editions produced in the interim? Why, after such a long gap, was the first new incarnation of the text in German?

Throughout the bibliographic scholarship on Pigafetta's account, certain common threads of confusion or doubt also exist. The foremost deals with the nature and circumstances of the c. I525 version, and as a corollary, the language in which Pigafetta composed his original text. Following a statement in Ramusio, the traditional understanding has been that Pigafetta first wrote a brief summary of events in Italian, which he presented to Louise de Savoy, the mother of King Francis I of France, at the behest of whom Jacques Antoine Fabre prepared a translation to French, which was published as the c. I525 first edition. According to this tradition, Pigafetta later composed a more complete version, in either French or Italian - the languages of the four extant manuscripts - that was not published until the Amoretti edition in I800. This is the story told, for example, by Sabin (I96I-I962 [I868]: 62803).

Others, however, disagree with this version. León Pinelo (I629, 88), Brunet (1999 [1862]: vol. IV, 650-65I), Harisse (I866, 229, 249), Robertson (1906b, 273), and Palau (I948-1980, 225739), among others, all seem to assert that Fabre did not work from an initial, short version, but rather from the full manuscript, which he abridged as well as translated. Robertson, for instance, terms the c. 1525 text «a summary made from the Italian manuscript» (I906b: 273). Two scholars offer particularly divergent opinions on this matter. Peckham (I969: VI-VII) seems to suggest that the 1525 first edition was Pigafetta's original text, not a translation, apparently proposing that Pigafetta had written in French, not Italian. Skelton, in contrast, looks skeptically on the Fabre story altogether, for which, as he points out, the only source is Ramusio (Skelton I969: I8).

If Skelton's doubt is merited, the legend of a Fabre translation stands as a notable example of hearsay or invention transforming itself, over the centuries, into apparent bibliographic truth. The bibliographic history of the Pigafetta text appears to harbor other ghosts as well. In some cases, we find the perpetuation of inaccurate information. For example, the 1784 Sprengel translation to German appears in Palau $(1848-1980,225748)$ as Erste Reise um die 
Welt durch Ferdinand Magelhan, which is, in truth, the title of the anthologized text that occupies pp. I-I55 in the volume Beiträge zur Völker und Länderkunde. 3 The Palau entry, which itself may be drawn from somewhere else, is repeated in the Cabrero edition $(1985,36)$ and elsewhere.

The 1884 French edition registered by the Bibliothèque Nationale de France may not actually exist, or may not exist as listed. Perhaps following the BNF catalog entry, however, Joseph Blanc (I972 [I886], col. I462), Palau (225747) and Giovanni Dotoli et al. (2004: 593) also register this text, for which scant evidence otherwise seems to exist. ${ }^{4}$

Other curiosities have not been perpetuated across various bibliographic works, but nonetheless may merit attention. For example, an edition printed in 197I in Buenos Aires purports to be based on an Italian version from I827 and a French text from 1798 . Neither of those texts appears to exist. ${ }^{5}$

Another tendency throughout the bibliographic tradition is for scholars to judge certain versions as inherently defective. Such criticism begins with the denigration of the hypothetical unknown Italian original from which the c. 1525 edition was supposedly derived. Apparently extrapolating from the language of the Ambrosiana manuscript or some other text, Harisse supposes that the French queen requested the translation because she could not comprehend «the kind of patois used by Pigafetta... which resembles a mixture of Italian or Venitian and Spanish» (I866, 249).

A critical view of the c. 1525 French edition is nearly universal. Harisse describes what he understands as Fabre's translation to be a «garbled version» that is «scarcely intelligible» $(\mathrm{I} 866,250)$. Robertson likewise uses the term «garbled» in discussing what he also assumes to be Fabre's translation (Igo6b, 273). All versions based on the c. 1525 are also, by extension, thought of as defective, with the version in Ramusio, for instance, generally considered to be a further deformation.

Despite its importance, the 1800 edition also does not escape criticism. Robertson says Amoretti «committed the sin of editing the precious docu-

3 This contains an introduction that begins on page 3 , but I have not been able to determine where the introduction ends and the text itself begins.

${ }_{4}$ See the catalog record at http://catalogue.bnf.fr/ark:/12148/cb31110657h. It may be one of the i2 volumes of «Nouvelle Bibliothèque des voyages».

5 The volume contains no introduction, name of editor or any additional information that might help clarify the case. 
ment, almost beyond recognition in places» (1906a, I4). As he states of Amoretti, «Unfortunately... he had the bad taste to try to put that document into good Italian, and in so doing made considerable changes both in text and meaning» (1906b, 295).

The edition of Lord Stanley of Alderley has been likewise decried. Robertson, for instance, questions Lord Stanley's mixing of source texts, observing that « $\mathrm{t}]$ he translation is not above reproach in several other ways besides the very unscholarly one of shifting from MS. 5650 to Amoretti». He additionally accuses the editor of «prudery» in his approach to the more graphic or salacious aspects of the text (I906b: $30 \mathrm{I}$ ).

After Robertson, editors have seemed less prone to engage in such freehanded criticism of their predecessors. Curiously, however, only Peckham (I969: XII) seems to have offered a vindication of the c. I525 edition, arguing that it is a textual fact that must be respected. Until I800, he points out, this was the only version available and hence was the text that informed a great deal of Early Modern thinking about the voyage and its ramifications. To date, no one seems to have similarly refuted previous evaluations of the i 800 edition and 1874 translation.

\section{CONCLUSION}

As we observe he five-hundreth anniversary of the Magellan-Elcano voyage, we find ourselves in an opportune moment to consider the complex history of the transmission of Pigafetta's account. This is also, perhaps, a time to look forward a few years to when we might celebrate the publication of the c. 1525 first edition, as well as to 2029, the four-hundredth anniversary of León Pinelo's Epitome, and hence the apparent inauguration of the bibliographical tradition surrounding the Pigafetta account. While scholars have invested much effort over the centuries, renewed attention to the transmission and related bibliographic scholarship is needed.

The implications of the current study go beyond the Pigafetta account. This article assumes that bibliographic traditions are valid objects of study, but little recent work explicitly of this nature seems to exist. This is a fact that we might find troubling; if the publication history of such a canonical text as Pigafetta's account remains incomplete, the same must surely be the case for many other key texts, as well as for lesser known but surely valuable works. 


\section{BIBLIOGRAPHY}

Alcedo, Antonio de (1964-1965 [1807]). Bibliotheca americana. Quito: Museo Municipal de Arte e Historia.

Amonetтi, Carlo (I800). «Introduzione». Antonio Pigafetta. Primo Viaggio Intorno al Globo Terracqueo. Ed. Carlo Amoretti. Milano: Nella stamperia di Giuseppe Galeazzi to Pigafetta, IX-LII.

Antonio, Nicolao (1788). Bibliotheca Hispana Nova. Matriti: Apud viudam et heredes Joachimi de Ibarra.

Bartlett, John Russell (1875 [1865]). Bibliotheca Americana. 2nd ed. Providence: Riverside Press.

Blanc, Joseph. (1972 [1886]). Bibliographie italico-française universelle. Genève: Slatkine Reprints.

Brunet, Jacques-Charles (1999 [1862]). Manuel du libraire et de l'amateur de livres. Genève: Slatkine Reprints.

Cachey, Theodore J. (1995). «Introduction». Antonio Pigafetta (1995). The First Voyage around the World (1519-1522): An Account of Magellan's Exploration. Ed. Theodore J. Cachey. New York: Marsilio to Pigafetta, VII-LIX. Rpt. in Pigafetta (2007), IX-LVIII. DотоLI, Giovanni [et al.] (2004). Les traductions de l'italien en français au xixe siècle. Fasano: Schena.

Graesse, Jean George Théodore (1859-1869). Trésor de livres rares et précieux. Genève: H. Georg.

Harisse, Henry (1866). Bibliotheca americana vetustissima. New York: Geo. P. Philes. Leclerc, Charles Alfred (I867). Bibliotheca Americana. Paris: Maisonneuve.

Leclerc, Charles Alfred (1878). Bibliotheca Americana. Paris: Maisonneuve.

León Pinelo, Antonio de (I629). Epitome de la biblioteca oriental i occidental, nautica i geografica. Madrid: Juan Gonzalez.

León Pinelo, Antonio de; González de Barcia Carballido y Zúñiga, Andrés (i7371738). Epitome de la bibliotheca oriental, y occidental, nautica, y geografica. Madrid: F. Martinez Abad.

Marsden, William (i827). Bibliotheca Marsdeniana. London: J. L. Cox.

Medina, José Toribio (1897). Biblioteca hispano-chilena (I523-1817). Santiago de Chile: en casa del autor.

Medina, José Toribio (1958-1962 [1898-1907]). Biblioteca hispanoamericana, I493-18Io. Santiago de Chile: Fondo Histórico y Bibliográfico José Toribio Medina.

Mosto, Andrea da (1894). «Introzuione». Antonio Pigafetta. Raccolta di documenti. Ed. Andrea da Mosto. Roma: Auspice Il Ministerio della Pubblica Istruzione, 7-I2. Nowell, Charles E. (1962). «Introduction». Antonio Pigafetta; Maximilian of Transylvania; Gaspar Corrêa. Magellan's Voyage Round the World: Three Contemporary Accounts. Evanston: Northwestern University Press, 3-76. 
Palau y Dulcet, Antonio (i948-i980). Manual del librero hispano-americano, 2nd ed. Barcelona: Librería Anticuaria de A. Palau.

Peckam, Howard H. (1969). «Introduction». Antonio Pigafetta. The Voyage of Magellan: The Journal of Antonio Pigafetta. Trans. Paula Spurlin Paige. Englewood Cliffs, New Jersey: Prentice-Hall, vI-XV.

Pigafetta, Antonio (c. I525). Le voyage et nauigation, faict par les Espaignolz es isles de Mollucques. Paris: par Simon de Colines.

Pigafetta, Antonio (1536). «Descrittione seconda del sopradetto viaggio». Il Viaggio fatto dagli Spagnivoli atorno a'l mondo. [Venice?]: s.n., fol. I3r-48r.

Pigafetta, Antonio (I550). «Viaggio attorno il mondo scritto per M. Antonio Pigafetta». Giovanni Battista Ramusio (ed.). Primo volume delle Navigationi et Viaggi. Venetia: appresso gli heredi di Lucantonio Giunti, 379v-397v.

Pigafetta, Antonio (I555). «A Briefe Declaration of the Vyage [...] About the Worlde». Decades of the New Worlde or West India. Ed. Richard Eden. Londini. Guilhelmi Powell, fol. 216v-232v.

Pigafetta, Antonio (I577). «A Briefe Declaration of the Viage [...] About the Worlde». History of Trauayle. Ed. Richard Eden. London: Richarde Iugge, fol. $43 \mathrm{IV}-447 \mathrm{~V}$.

Pigafetta, Antonio (i625-I626). «Of Fernandus Magalianes [...]». Purchas His Pilgrimes. Ed. Samuel Purchas. London: Printed for William Stansby, v. I, book 2, 84-II9.

Pigafetta, Antonio (I784). «Erste Reise um die Welt durch Ferdinand Magelhan [...] Aus dem Ital». Beiträge zur Völker und Länderkunde, Ed. M. C. Sprengel, v. IV. Leipzig: Weygand, I-I55.

Pigafetta, Antonio (i800). Primo Viaggio Intorno al Globo Terracqueo. Ed. Carlo Amoretti. Milano: Nella stamperia di Giuseppe Galeazzi.

Pigafetta, Antonio (i8oi). Premier Voyage autour du monde. Trans. Carlo Amoretti. Paris: H.-J. Jansen.

Pigafetta, Antonio (I80I). Beschreibung der von Magellan unternommenen ersten Reise um die Welt. Gotha: Jurus Perthes.

Pigafetta, Antonio (I8I2). «Pigafetta's voyage round the world». Trans. John Pinkerton. A General Collection of the Best and Most Interesting Voyages and Travels. London: Longman, I812, v. II, 288-420.

Pigafetta, Antonio (i854-1857). Voyageurs anciens et modernes. Ed. Edouard Charton. Paris: Aux Bureaux Du Magasin Pittoresque, v. III, 273-356.

Pigafetta, Antonio (I874). «Pigafetta's Account of Magellan's Voyage». The First Voyage Round the World, by Magellan. Ed., trans. Lord Stanley of Alderley. London: Printed for the Hakluyt Society, 35-163.

Pigafetta, Antonio ([I884]). Voyage de Magellan autour du monde [...], traduit de l'italien par R.P. Limoges: M. Barbou. 
Pigafetta, Antonio (1885). «The First Circumnavigation of the Globe». The First Three English Books on America. Ed. Edward Arber. Birmingham: I Montague Road, 249262.

Pigafetta, Antonio (i888a). Premier voyage autour du monde. Paris: Ch. Delagrave.

Pigafetta, Antonio (1888b). «Navegacion y descubrimiento de la India Superior». Colección de documentos inéditos para la historia de Chile (1888-1902). Trans. José Toribio Medina. Santiago de Chile: Imprenta Ercilla, v. II, 417-524.

Pigafetta, Antonio (I894). «Relazione sul primo viaggio intorno al globo». Raccolta di documenti. Ed. Andrea da Mosto. Roma: Auspice Il Ministerio della Pubblica Istruzione, part V, V. III, 7-I3I.

Pigafetta, Antonio (1899). Primer viaje alrededor del mundo. Ed., trans. Manuel Walls y Merino. Madrid [s. n.].

Pigafetta, Antonio (1906). Magellan's Voyage around the World. Trans. James Alexander Robertson. Cleveland: Arthur H. Clark.

Pigafetta, Antonio (I922). Primer viaje en torno del globo. Trans. Federico Ruiz Morcuende. Madrid: Calpe.

Pigafetta, Antonio (1923). Relation du premier voyage autour du monde par Magellan, 1519-1522. Ed. Jean Denucé. Paris: E. Leroux.

Pigafetta, Antonio (1928). Relazione del primo viaggio intorno al mondo. Ed. Camilo Manfroni. Milano: Alpes.

Pigafetta, Antonio (1938). Fernão de Magalhãis. Lisboa: Seara Nova.

Pigafetta, Antonio (1956). Relation du premier voyage autour du monde par Magellan, I519-1522. Ed. Léonce Peillard. Paris: Club des Libraries de France.

Pigafetta, Antonio (1957). «Relación del primer viaje alrededor del mundo». Trans. F. Ros. América en los grandes viajes. Madrid: Aguilar, 2I-7I.

Pigafetta, Antonio (1962). «First Voyage Around the World». Antonio Pigafetta; Maximilian of Transylvania; Gaspar Corrêa. Magellan's Voyage Round the World: Three Contemporary Accounts. Ed. Charles E. Nowell. Evanston: Northwestern University Press, 85-268.

Pigafetta, Antonio (1964). First Around the World: A Journal of Magellan's Voyage. Ed. George Sanderlin. New York: Harper and Row.

Pigafetta, Antonio (1969a). «First Voyage Around the World». First Voyage Around the World. Manila: Filipiniana Book Guild, I-ror.

Pigafetta, Antonio (1969b). Magellan's Voyage: A Narrative of the First Circumnavigation. Ed., trans. R. A. Skelton. New Haven: Yale Univ. Press.

Pigafetta, Antonio (1969c). The Voyage of Magellan: The Journal of Antonio Pigafetta. Trans. Paula Spurlin Paige. Englewood Cliffs, New Jersey: Prentice-Hall.

Pigafetta, Antonio (1970). Primer viaje en torno del globo. Trad. Armando Braun Menéndez. Buenos Aires: Aguirre. 
Pigafetta, Antonio (197i). Primer viaje en torno del globo. Buenos Aires: Centro Editor de América Latina.

Pigafetta, Antonio (1985). Primer viaje alrededor del mundo. Ed. Leoncio Cabrero. Madrid: Historia I6.

PigafetTA, Antonio (1987). Viaggio attorno al mondo. Ed. Mariarosa Masoero. Rovereto: Longo. (Cachey LiII)

Pigafetta, Antonio (1989). La mia longa et pericolosa navigatione: la prima circumnavigazione del globo (1519-1522). Ed. Luigi Giovannini. Milano: Edizioni Paoline.

Pigafetta, Antonio (I99i). «Da "Notizie del Mondo Nuovo"». Scopritori e viaggiatori del Cinquecento e del Seicento. Ed. Mario Pozzi. Milano: Ricciardi, 509-7I.

Pigafetta, Antonio (1994). Il primo viaggio intorno al mondo. Ed. Mario Pozzi. Vicenza: Neri Pozza.

Pigafetta, Antonio (1995). The First Voyage around the World (1519-1522): An Account of Magellan's Exploration. Ed. Theodore J. Cachey. New York: Marsilio.

Pigafetta, Antonio (1999a). Relazione del primo viaggio attorno al mondo. Ed. Andrea Canova. Padova: Editrice Antenore.

Pigafetta, Antonio (1999b). El Primer viaje alrededor del mundo. Trad. Isabel de Riquer. Barcelona: Ediciones B.

Pigafetta, Antonio (2004). Primer viaje en torno del globo. Ed. Martín Casariego. Madrid: Espasa-Calpe.

PigafetTA, Antonio (2007). Le voyage de Magellan (1519-1522): la relation d'Antonio Pigafetta E autres témoignages. Ed. Xavier de Castro. Paris: Chandeigne.

Payne, John Thomas; Foss, Henry (1842). Bibliotheca Grenvilliana. London: William Nicol.

Peillard, Léonce (1956). «Preface». Antonio Pigafetta. Relation du premier voyage autour du monde par Magellan, 1519-1522. Ed. Léonce Peillard. Paris: Club des Libraries de France, 7-I22.

Pozzi, Mario (199I). «Introduzione». Scopritori e viaggiatori del Cinquecento e del Seicento. Ed. Mario Pozzi. Milano: Ricciardi, 5II-523.

Pozzi, Mario (1994). «Introduzione». Antonio Pigafetta Il primo viaggio intorno al mondo. Ed. Mario Pozzi. Vicenza: Neri Pozza, v. I, 9-ıo6.

Robertson, James Alexander (1906a). «Preface». Antonio Pigafetta. Magellan's Voyage around the World. Trans. James Alexander Robertson. Cleveland: Arthur H. Clark, V. I, I3-I8.

Robertson, James Alexander (1906b). «Bibliography of Pigafetta Manuscripts and Printed Books». Antonio Pigafetta (1906). Magellan's Voyage around the World. Trans. James Alexander Robertson. Cleveland: Arthur H. Clark (I906), v. III, 24I3 I3.

SABIN, Joseph (1961-1962 [1868]). A Dictionary of Books Relating to America. Amsterdam: N. Israel. 
Skelton, R. A. (1969). «Introduction». Antonio Pigafetta. Magellan's Voyage: A Narrative of the First Circumnavigation. Ed., trans. R. A. Skelton. New Haven: Yale Univ. Press, V. I, I-28.

StAnley, Henry Edward John (Lord Stanley of Alderley) (I874). «Introduction». Antonio Pigafetta. The First Voyage Round the World, by Magellan. New York: Burt Franklin, I-LX. Works Issued by the Hakluyt Society, First Series, no. 52.

Ternaux-Compans, Henri (i83i). Bibliotheca Americana. Paris: Paul Renouard.

Ternaux-Compans, Henri (1837). Bibliothèque américaine. Chicago: Paris: Arthus-Bertand.

WINsOR, Justin (1886). Spanish Explorations and Settlements in America from the Fifteenth to the Seventeenth Century. Boston: Houghton, Mifflin. 